Journal of Leukocyte Biology 48:97-102 (1990)

REVIEW

\title{
Mechanisms of Neutrophil-Mediated Killing of Endothelial Cells
}

\author{
Peter A. Ward and James Varani \\ Department of Pathology, The University of Michigan Medical School, Ann Arbor
}

\section{INTRODUCTION}

The killing of endothelial cells either by activated neutrophils or by addition of $\mathrm{H}_{2} \mathrm{O}_{2}$ has been extensively studied. Several different, important themes related to the mechanism of cell killing have recently emerged. 1) Depending on their origin, the susceptibility of endothelial cells to oxidant-mediated killing by neutrophils varies. 2) In some respects, the killing of endothelial cells by activated neutrophils involves a participation of endothelial cells in their own destruction. 3) The killing of endothelial cells by products of neutrophils does not occur by a single, commonly accepted biochemical event. 4) Endothelial cell killing appears to be mediated by synergistic interaction of oxygen products and proteases from leukocytes. 5) Finally, endothelial cells can be modified by contact with cytokines such that their susceptibility to killing by neutrophils is greatly enhanced.

\section{VARIATION IN SUSCEPTIBILITY OF ENDOTHELIAL CELLS TO NEUTROPHIL-MEDIATED DAMAGE}

There are several bodies of evidence suggesting that endothelial cell damage by phorbol ester-activated neutrophils varies with regard to the mechanism of injury. Human umbilical vein endothelial cells and rat pulmonary artery endothelial cells have been reported to be susceptible to damage by neutrophils in a manner that is related to the generation of toxic oxygen products from neutrophils [1-4]. The damage can be largely abrogated by catalase and by the iron chelator deferroxamine but not by superoxide dismutase (SOD), suggesting that an iron-dependent product of $\mathrm{H}_{2} \mathrm{O}_{2}$, perhaps the hydroxyl radical (HO-), is the damaging oxygen product. In addition, if neutrophils from patients with chronic granulomatous disease (CGD) are employed, little or no endothelial cell injury occurs, consistent with the conclusion that injury is due to a toxic oxygen product of the respiratory burst. In contrast, microvascular endothelial cells obtained from human omentum are injured by contact with phorbol ester-activated neutrophils obtained from normal human volunteers or from patients with CGD, and catalase is nonprotective $[5,6]$. The protective effects of chlormethyl ketone inhibitors, which inactivate the catalytic site in elastase, have been taken to suggest that this type of endothelial cell injury is related to the effect of a granule-released product, such as elastase. Collectively, these data indicate that, within the same species, endothelial cells may be injured by neutrophils via two independent mechanisms, one being oxygen radical-mediated and the other being independent of this pathway. In addition to these pathways of cytotoxic injury, endothelial cell monolayers may be disrupted by neutrophil products (presumably proteolytic enzymes) without being killed, the outcome of which may be loss in vivo of the endothelial cell covering of vessels and compromise of the permeability barrier $[7,8]$.

Additional evidence suggesting that endothelial cells from different vascular beds vary significantly with respect to the mechanism of neutrophil-mediated injury comes from some recent in vivo observations in rats. Immune complex deposition (involving rabbit polyclonal IgG antibody to bovine serum albumin) has been induced in the lungs and dermis by the local injection (into airways or dermis) of antibody and the systemic injection of antigen. Immune complex deposition occurs in alveolar walls of lung and in venules and capillaries of the dermis, leading to complement-dependent and neutrophildependent vascular injury, which results in endothelial cell damage, increased vascular permeability, and hemorrhage. Vascular injury in the lung is significantly diminished if catalase is intermixed with the antibody or if the animals are systemically treated with the iron chelator deferroxamine [9]. In striking contrast, no protection from injury is obtained in the dermis under the same

Received February 8, 1990; accepted February 8, 1990.

Reprint requests: Peter A. Ward, Department of Pathology, The University of Michigan Medical School, 1301 Catherine Street, Box 0602, Ann Arbor, MI 48109-0602. 
conditions of treatment, even when catalase is covalently linked to the IgG [9]. This striking discordance in effects of interventions (catalase and deferroxamine) strongly suggests that, whereas endothelial cells in both the lung and the dermis are damaged by products of activated neutrophils, toxic oxygen products are vital for damage of lung microvascular endothelial cells and irrelevant to damage of dermal vascular endothelial cells. Very little is known regarding the mechanism by which dermal vascular endothelial cells are damaged by products of activated neutrophils. More definitive studies will probably require access to primary cultures of microvascular endothelial cells from each of the two organs, but to date we have not been successful in culturing dermal microvascular endothelial cells in sufficient quantities to carry out the necessary studies.

\section{PARTICIPATION OF ENDOTHELIAL CELLS IN THEIR KILLING BY NEUTROPHILS}

As strange as it may seem, there is now incontrovertible evidence that, in the interaction of phorbol esterstimulated neutrophils and endothelial cells, the latter play an active role in events leading to their own damage and/or destruction. Collectively, the participation of endothelial cells in their demise by activated neutrophils can be considered an "autotoxic" response of endothelial cells. There are two bodies of evidence that support this conclusion. The first relates to the killing of rat pulmonary artery endothelial cells by human neutrophils. It has been shown that this killing requires oxygen products of the neutrophil [1-4]. On the basis of the protective effects of catalase, deferroxamine, and HO- scavengers such as dimethyl thiourea and dimethyl sulfoxide, it seems likely that $\mathrm{HO}$ - may be the key reactive species of oxygen responsible for the killing process. Inasmuch as it has been demonstrated that phorbol-activated human neutrophils generate $\mathrm{O}_{2}{ }^{-}$and $\mathrm{H}_{2} \mathrm{O}_{2}$ but not $\mathrm{HO}$. unless iron is added to the extracellular fluid [10], the observation related to the iron requirement for neutrophil killing of endothelial cells implies that iron is available either from the extracellular fluid or from the endothelial cell itself. Accordingly, rat pulmonary artery endothelial cells have been pretreated with deferroxamine and washed and then neutrophils have been added. Their ability to kill the endothelial cells was assessed after addition of phorbol ester. The results were striking: Pretreatment of endothelial cells with deferroxamine led to almost $70 \%$ reduction in their killing by activated neutrophils [11]. It could be demonstrated by high-performance liquid chromatography that extracts of the deferroxamine-treated cells contained deferroxamine that was bound to iron $\left(\mathrm{Fe}^{3+}\right)$. The location within the endothelial cell of the iron-deferroxamine complex (which might provide vital information related to where in the endothelial cell engagement of iron in a manner that leads to damage occurs) is not known; this finding demonstrates that the deferroxamine has intercepted iron within the endothelial cell and that this iron is related to the cytotoxic events. On the basis of this information, it can be concluded that neutrophil-mediated killing of endothelial cells requires the engagement of iron from the target cell. The presumption is that iron is released and converted by $\mathrm{O}_{2}^{-}$to its transition state $\left(\mathrm{Fe}^{2+}\right)$, which permits it to react with $\mathrm{H}_{2} \mathrm{O}_{2}$ to generate $\mathrm{HO}$.

A second line of evidence for autotoxic responses of endothelial cells comes from recent observations that rat pulmonary artery endothelial cells contain xanthine dehydrogenase (xd) and xanthine oxidase (xo) in a ratio of approximately $2: 1$. If endothelial cells are pretreated with inhibitors of xo, namely, allopurinol and oxypurinol, and then washed, the ability of phorbol ester-activated neutrophils to kill these cells is greatly attenuated, in proportion to the concentration of inhibitor employed [12]. In parallel experiments, pretreatment of neutrophils does not attenuate their ability to kill endothelial cells, indicating that the effect of allopurinol and oxypurinol is related to their interaction with the endothelial cell. Although allopurinol might be functioning as a scavenger of $\mathrm{HO}$, it seems unlikely that this explains the protective effects of the inhibitor, since the scavenging ability of allopurinol requires millimolar concentrations. A more plausible explanation is that these compounds inhibit $x d$ and/or xo in the treated endothelial cells, a finding that has been confirmed by direct measurements of $x d$ and xo in the treated endothelial cells. These observations imply that availability of $x d$ and/or xo in endothelial cells is linked to destruction of these cells by activated neutrophils. Perhaps relevant to these findings is the fact that, when phorbol ester-stimulated neutrophils interact with endothelial cells, there is a fairly rapid conversion of $\mathrm{xd}$ to $x o$ (with an inversion of $x d / x o$ the ratio from 2:1 to $1: 2$ ), with the conversion being irreversible (not reversible by the addition of reducing agents). The addition of catalase, superoxide dismutase (SOD), or deferroxamine fails to prevent conversion of $x d$ to $x o$ in the endothelial cells following activation of neutrophils. Also, CGD cells are fully effective in causing conversion of $\mathrm{xd}$ to $\mathrm{xo}$, providing compelling evidence that the conversion process is not related to an oxygen products of the neutrophil [12]. Although it can be speculated that the neutrophilderived "converting factor" may be a granule secretion product, this is not proven at present.

On the basis of these data, it seems possible that neutrophil interaction with endothelial cells results in additional xo activity, which will provide for more generation of $\mathrm{O}_{2}{ }^{-}$within the endothelial cell, adding to the oxygen radical burden of the cell. A more comprehen- 
sive analysis of how this fits into the scheme of events leading to injury or death of endothelial cells is presented below.

\section{BIOCHEMICAL EVENTS RELATED TO INJURY OF ENDOTHELIAL CELLS}

There is no consensus regarding the biochemical events that can be linked to damage or killing of endothelial cells by toxic oxygen products from activated neutrophils or by the addition of reagent $\mathrm{H}_{2} \mathrm{O}_{2}$. As referred to above, rat pulmonary artery endothelial cells are killed over a period of several hours following exposure to phorbol ester-activated human neutrophils, using effector/target cell ratios as small as $2: 1[4,11,12]$. Since neutrophils from patients with CGD fail to induce killing, the process of cell injury is linked to oxygen products of the respiratory burst. Furthermore, catalase but not SOD is protective, as are the HO- scavengers such as DMSO and DMTU. Although it is possible that the cell killing process could be related to the formation of iron radicals (ferryl and/or perferryl ions), the role of $\mathrm{HO}^{-}$also seems likely. The killing of endothelial cells by $\mathrm{H}_{2} \mathrm{O}_{2}$ follows a similar pattern of protective interventions, indicating that extrinsic $\mathrm{O}_{2}^{-}$is not essential for the cytolytic pathway. The evidence (referred to above) that inhibitors of endothelial cell xo (and $x d$ ) will block a significant amount of neutrophil-mediated killing suggests that intracellular formation of $\mathrm{O}_{2}^{-}$within the endothelial cell is somehow linked to the cell killing process. We speculate that intracellular formation of $\mathrm{O}_{2}^{-}$(whether by xo, cyclooxygenase, mitochondrial enzymes, or some other source) brings about release of $\mathrm{Fe}^{3+}$ from its storage form in ferritin and formation of $\mathrm{Fe}^{2+}$, which can then interact with $\mathrm{H}_{2} \mathrm{O}_{2}$ (which has diffused into the endothelial cell after its formation on the cell membrane of the neutrophil), following which $\mathrm{H}_{2} \mathrm{O}_{2}$ is reduced to $\mathrm{HO}$. and $\mathrm{Fe}^{2+}$ is recycled to $\mathrm{Fe}^{3+}$. The influx of $\mathrm{H}_{2} \mathrm{O}_{2}$ into the endothelial cell would also be expected to result in a fall in intracellular levels of ATP, because of both impaired synthesis and accelerated breakdown [13-21]. Even after the fall in ATP, a rise in intracellular calcium due to influx from the extracellular compartment would be expected [22-28].

It is not at all clear what biochemical events can be directly linked to cell injury. Although it is known that $\mathrm{H}_{2} \mathrm{O}_{2}$ and other oxygen products (including hypochlorous acid $(\mathrm{HOCl})$, a halide metabolite resulting from the action of myeloperoxidase on $\mathrm{H}_{2} \mathrm{O}_{2}$ ) can react with surface molecules on cell membranes [29], to what extent these effects are relevant to cytotoxicity is not known. It is known that $\mathrm{H}_{2} \mathrm{O}_{2}$ can inactivate glyceraldehyde3-phosphate dehydrogenase [21] and also bring about activation of ADP-ribose polymerase [14], the result of which can cause a fall in intracellular levels of NAD. Whether these findings can be generalized to include mechanisms of cytotoxicity in endothelial cells is not known. We have not been able to demonstrate that the inhibitor of ADP-ribose polymerase, namely, 3aminobenzidine, will protect endothelial cells from $\mathrm{H}_{2} \mathrm{O}_{2}$-mediated damage (Varani, J., and Ward, P.A., unpublished data). Furthermore, the observation that red blood cell killing by oxygen products of neutrophils involves a role for $\mathrm{O}_{2}^{-}[30]$ and the fact that red blood cells lack ADP-ribose polymerase suggests the likelihood of multiple explanations for biochemical events related to neutrophil or $\mathrm{H}_{2} \mathrm{O}_{2}$-mediated killing of endothelial cells.

\section{ENDOTHELIAL KILLING: SYNERGY BETWEEN PROTEASES AND $\mathrm{H}_{2} \mathrm{O}_{2}$}

Recent evidence indicates that endothelial cells (from the rat pulmonary artery) are killed following addition of $\mathrm{H}_{2} \mathrm{O}_{2}$ in a time-dependent process. The endpoint, which is release of ${ }^{51} \mathrm{Cr}$, is ordinarily established at $4 \mathrm{hr}$ for convenience, even though the release of ${ }^{51} \mathrm{Cr}$ continues for a total period of $8 \mathrm{hr}$, following which there is plateau in the release of ${ }^{51} \mathrm{Cr}$. During the first $4 \mathrm{hr}$, the addition of protease inhibitors such as soybean trypsin inhibitor (SBTI) does not reduce the release of ${ }^{51} \mathrm{Cr}$. However, when the endpoint of $18 \mathrm{hr}$ is used, the continued presence of catalase $(180$ units $/ \mathrm{ml})$ alone produced $10 \% \pm$ $1 \%$ protection, the continued presence of SBTI produced $35 \% \pm 4 \%$ protection whereas the combination of catalase and SBTI yielded $78 \% \pm 5 \%$ protection, implying that over this extended period there may be synergistic effects of $\mathrm{H}_{2} \mathrm{O}_{2}$ and proteases, the result of which is intensified cell injury [31]. The experiments were then extended to employ addition of porcine pancreatic elastase $(2.3$ units $/ \mathrm{ml})$, which at $18 \mathrm{hr}$ caused $13 \% \pm 1 \%$ release of ${ }^{51} \mathrm{Cr}, \mathrm{H}_{2} \mathrm{O}_{2}(100 \mathrm{nmol})$, which in the same period of time caused $33 \% \pm 1 \%$ release of ${ }^{51} \mathrm{Cr}$, or the combination of elastase and $\mathrm{H}_{2} \mathrm{O}_{2}$, the result of which was $75 \% \pm 2 \%$ release of ${ }^{51} \mathrm{Cr}$. Similar results have been obtained with the use of trypsin and chymotrypsin. These data show beyond reasonable question that, under the experimental conditions employed, proteases and $\mathrm{H}_{2} \mathrm{O}_{2}$ act in synergistic manner to bring about cytotoxic events (defined by ${ }^{51} \mathrm{Cr}$ release) in the endothelial cell. There is at present no explanation for how this occurs, why a prolonged duration of contact of these substances with the endothelial cell is required, and whether the ${ }^{51} \mathrm{Cr}$ release at $4 \mathrm{hr}$ vs. $18 \mathrm{hr}$ involves different mechanisms of cytotoxicity. Obviously, much additional work is required. 


\section{EFFECTS OF CYTOKINES ON NEUTROPHIL MEDIATED KILLING OF ENDOTHELIAL CELLS}

Cytokines have a plethora of biological effects on a variety of different cells. With regard to phagocytic cells, tumor necrosis factor- $\alpha$ (TNF $\alpha$ ) and interleukin- $1 \beta$ (IL-1 $\beta$ ) can "prime" these cells for exaggerated oxygen radical responses [32-34]. At much higher concentrations, direct stimulation of neutrophils and macrophages by cytokines occurs. The ability of these cytokines to alter endothelial cells in a manner that leads to increased adhesive interactions with neutrophils is a well-known phenomenon [35-37]. This is a slowly developing process of up-regulation in the endothelial cell, requires several hours, and depends on protein synthesis, probably involving increased expression on the endothelial cell of at least two different adhesion-promoting molecules. The complementary adhesion-reactive molecule on the neutrophil involves the CR3 (complement receptor) moiety and probably, to a lesser extent, at least one other adhesion-related molecule. Not only does prior exposure of endothelial cells to TNF $\alpha$ or IL- $1 \beta$ lead to augmented adhesive interactions with neutrophils, this also results in a greatly enhanced (two- to threefold) cytotoxic outcome in the presence of phorbol ester activated neutrophils [38]. Whether the increased killing of endothelial cells is a reflection solely of enhanced adhesive interactions with neutrophils or whether other mechanisms are also responsible for the enhanced cytotoxicity is not currently known. It should be noted that the ability of TNF to cause rapid conversion of $x d$ to $x o$ in endothelial cells may be another event that puts these cells at added risk of injury [39]. By whatever mechanism the enhanced cytotoxicity occurs, these observations may be relevant to clinical studies featuring the infusion of TNF into humans, in which case evidence for serious acute injury of the pulmonary microvasculature has been obtained.

Another finding of relevance to these issues comes from recent observations that, whereas exposure of human umbilical vein endothelial cells to TNF does not itself result in evidence of cell injury when the cells are examined immediately after exposure, if endothelial cells exposed for $18 \mathrm{hr}$ to as little as $2 \mathrm{ng} \mathrm{TNF} \alpha / \mathrm{ml}$ are then washed and placed in a simple culture medium (Hanks balanced salt solution), there is progressive evidence of cell injury over the next $4 \mathrm{hr}$, as reflected by ${ }^{51} \mathrm{Cr}$ release [40]. The cytotoxic effects are abrogated if the TNF $\alpha$ used for the $18 \mathrm{hr}$ treatment regimen is either heat-inactivated or blocked by the addition of specific antibody. IL-1 $\beta$ has similar effects, whereas M-CSF is without any effect on the endothelial cells. Furthermore, endothelial cells show a degree of specificity for the effects of TNF $\alpha$ inasmuch as neither human dermal fibroblasts nor squamous epithelial cells from skin develop evidence of cytotoxic effects after exposure to TNF $\alpha$. Although the manner by which TNF $\alpha$ causes susceptibility of endothelial cells to toxic effects under these special conditions is unknown, the fact the deferroxamine is protective suggests that an iron-dependent pathway of toxicity is involved. Not surprising, allopurinol is not protective, in accordance with the fact that human umbilical vein endothelial cells are largely devoid of detectable xd and xo. However, the ability of several cyclooxygenase inhibitors (ibuprofen, indomethacin, piroxicam) to protect against the toxicity following exposure of endothelial cells to TNF $\alpha$ may imply that generation of $\mathrm{O}_{2}{ }^{-}$from cyclooxygenase is relevant to the mechanism of injury. These data indicate that exposure of endothelial cells to TNF $\alpha$ and $I L-1 \beta$ alters these cells in a manner that makes them significantly susceptible to injury, by either direct or indirect (neutrophil-mediated) pathways.

\section{CONCLUSIONS}

As is evident from this information, endothelial cells have very complex biological responses that have important implications for the outcome of the inflammatory response. The recognition that the susceptibility of endothelial cells to injury may vary considerably, depending on the species of origin or the source of the microvascular bed from which the cells originate, has important implications suggesting that there is a significant diversity in behavior of endothelial cells. The increasing recognition that the events related to how endothelial cells are injured by products of activated neutrophils are complex and involve factors originating both in the effector cells (neutrophils) as well as in the target (endothelial) cells adds a new dimension and suggests that a variety of different therapeutic interventions may be employed for the protection of endothelial cells during the inflammatory response. Finally, the increasing knowledge that endothelial cells can respond directly to inflammatory mediators suggests that a more detailed analysis of signal-transduction events in these cells should provide some important clues to their biology.

\section{ACKNOWLEDGMENTS}

This work was supported in part by NIH grants HL31963, HL-07517, and GM-29507 and by grant IM-432 from the American Cancer Society.

\section{REFERENCES}

1. Sacks, T., Moldow, C.F., Craddock, P.R., Bowers, T.K., and Jacob, H.S. Oxygen radicals mediate endothelial cell damage by 
complement-stimulated granulocytes: An in vitro model of immune vascular damage. J. Clin. Invest. 61,1161-1169, 1978.

2. Martin, W.J. Neutrophils kill pulmonary endothelial cells by a hydrogen peroxide-dependent pathway. An in vitro model of neutrophil-mediated lung injury. Am. Rev. Respir. Dis. 130,209$214,1984$.

3. Weiss, S.J., Young, J., LoBuglio, A.F., Slivka, A., and Nimeh, N.F. Role of hydrogen peroxide in neutrophil-mediated destruction of cultured endothelial cells. J. Clin. Invest. 68,714-718, 1981.

4. Varani, J., Fligiel, S.E.G., Till, G.O., Kunkel, R.G., Ryan, U.S., and Ward, P.A. Pulmonary endothelial cell killing by human neutrophils: Possible involvement of hydroxyl radical. Lab. Invest. 53,656-663, 1985.

5. Smedly, L.A., Tonnesen, M.G., Sandhaus, R.A., Haslett, C., Guthrie, L.A., Johnson, R.B., Henson, P.M., and Worthen, G.S. Neutrophil-mediated injury to endothelial cells: Enhancement by endotoxin and essential role of neutrophil elastase. J. Clin. Invest. 77,1233-1243, 1986.

6. Pontremoli, S., Melloni, E., Michetti, M., Sacco, O., Sparatore, B., Salamino, F., Damiani, G., and Horecker, B.L. Cytolytic effects of neutrophils: Role for a membrane-bound neutral proteinase. Proc. Natl. Acad. Sci. USA 83,1685-1689, 1986.

7. Harlan, J.M., Killen, P.D., Harker, L.A., Striker, G.E., and Wright, D.G. neutrophil-mediated endothelial injury in vitro: Mechanisms of cell detachment. J. Clin. Invest. 68,1394-1399, 1981.

8. Harlan, J.M., Schwartz, B.R., Reidy, M.A., Schwartz, S.M., Ochs, H.D., and Harker, L.A. Activated neutrophils disrupt endothelial monolayer integrity by an oxygen radical-independent mechanism. Lab. Invest. 52,141-150, 1985.

9. Warren, J.S., Yabroff, K.R., Mandel, D.M., Johnson, K.J., and Ward, P.A. Role of $\mathrm{O}_{2}^{-}$in neutrophil recruitment into sites of dermal and pulmonary vasculitis. Free Radical Biol. Med. (in press).

10. Cohen, M.S., Britigan, B.E., Hassett, D.J., and Rosen, G.M. Do humans neutrophils form hydroxyl radical. Evaluation of an unresolved controversy. Free Radical Biol. Med. 5,81-88, 1988.

11. Gannon, D.E., Varani, J., Phan, S.H., Ward, J.H., Kaplan, J., Till, G.O., Simon, R.H., Ryan, U.S., and Ward, P.A. Source of iron in neutrophil-mediated killing of endothelial cells. Lab. Invest. 57,37-44, 1987.

12. Phan, S.H., Gannon, D.E., Varani, J., Ryan, U.S., and Ward, P.A. Xanthine oxidase activity in rat pulmonary artery endothelial cells and its alteration by activated neutrophils. Am. J. Pathol. 134,1201-1211, 1989.

13. Schraufstatter, I.U., Hyslop, P.A., Jackson, J.H., and Cochrane, C.G. Oxidant-induced DNA damage of target cells. J. Clin. Invest. 82,1040-1050, 1988.

14. Schraufstatter, I.U., Hinshaw, D.B., Hyslop, P.A., Spragg, R.G., and Cochrane, C.G. Oxidant injury to cells: DNA strand breaks activate polyadenosine diphosphate-ribose polymerase and leads to depletion of nicotinamide adenine dinucleotide. J. Clin. Invest. 77,1312, 1986.

15. Atkinson, D.E. Cellular Energy Metabolism and Its Regulation. New York: Academic Press, 1977.

16. Spragg, R.G., Hinshaw, D.B., Hyslop, P.A., Schraufstatter, I.U., and Cochrane, C.G. Alterations in adenosine triphosphate and energy charge in cultured endothelial and P388D, cells after oxidant injury. J. Clin. Invest. 76,1471-1476, 1985.

17. Holmsen, H., and Robbin, L. Hydrogen peroxide lowers ATP levels in platelets without altering energy charge and platelet function. J. Biol. Chem. 252,1752-1757, 1977.

18. Jennings, R.B., Hawkins, H.K., Lowe, J.E., Hill, M.L., Klot- man, S., and Reimer, K.A. Relation between high energy phosphate and lethal injury in myocardial ischemia in dogs. Am. J. Pathol. 92,187-214, 1977.

19. Rajs, J., Sundberg, M., Harm, T., Grandinsson, M., and Soderlund, U. Interrelationships between ATP levels, enzyme leakage, gluconate uptake, trypan blue exclusion, and length/width ratio of isolated rat cardiac myocytes subjected to anoxia and reoxygenation. J. Mol. Cell. Cardiol. 12,1227-1238, 1980.

20. Kane, A.B., Petrovich, D.R., Stern, R.O., and Farber, J.L. ATP depletion and loss of cell integrity in anoxic hepatocytes and silica-treated P388D, macrophages. Am. J. Physiol. 249,C256C266, 1985.

21. Hyslop, P.A., Hinshaw, D.B., Halsey, W.A., Schraufstatter, I.U., Jackson, J.H., and Spragg, R.A., Sauereber, R.D., and Cochrane, C.G. Mechanisms of oxidant mediated cell killing. The glycolytic and mitochondrial pathways of ADP phosphorylation are major targets of $\mathrm{H}_{2} \mathrm{O}_{2}$-mediated injury. J. Biol. Chem., 263,1665-1675, 1988.

22. Tzeng, W.-F., and Chen, Y.-H. Suppression of snake venom cardiotoxin-induced cardiomyocyte degeneration by blockage of $\mathrm{Ca}^{2+}$ influx or inhibition of nonlysosomal proteinases. Biochem. J. 256,89-95, 1988.

23. Nicotera, P., Hartzell, P., Baldi, C., Svenson, S.-A., Bellomo, G., and Orrenius, S. Cystamine induces cytotoxicity in hepatocytes through elevation of cytosolic $\mathrm{Ca}^{2+}$ and the stimulation of a nonlysosomal proteolytic system. J. Biol. Chem. 261,14628$14635,1986$.

24. Glende, E.A., and Pushpendron, K.C. Activation of phospholipase $A_{2}$ by carbon tetrachloride in isolated rat hepatocytes. Biochem. Pharmacol. 35,3301-3307, 1986.

25. McConkey, D.J., Hartzell, P., Nicotera, P., and Orrenius, S. Calcium-activated DNA fragmentation kills immature thymocytes. FASEB J. 3, 1843-1849, 1989.

26. DiMonte, D., Bellomo, G., Thor, H., Nicotera, P., and Orrenius, S. Menadione-induced cytotoxicity is associated with protein thiol oxidation and alteration in intracellular $\mathrm{Ca}^{2+}$ homeostatsis. Arch. Biochem. Biophys. 235,343-350, 1984.

27. Nicotera, P., McConkey, D., Svensson, S.-A., Bellomo, G., and Orrenius, S. Correlation between cytosolic $\mathrm{Ca}^{2+}$ concentration and cytotoxicity in hepatocytes exposed to oxidative stress. Toxicology $52,55-63,1988$.

28. Starke, P.E., Hoels, J.B., and Farber, J.L. Calcium-dependent and calcium-independent mechanisms of irreversible cell injury in cultured hepatocytes. J. Biol. Chem. 261,3006-3012, 1986.

29. Schraufstatter, I.U., Hyslop, P.A., Jackson, J., and Cochrane, C.G. Cellular targets of $\mathrm{H}_{2} \mathrm{O}_{2}$ and $\mathrm{HOCl}$ induced injury. Basic Life Sci. 49,833-837, 1988.

30. Weiss, S.J. Tissue destruction by neutrophils. N. Engl. J. Med. 320,365-375, 1989.

31. Varani, J., Ginsburg, I., Schuger, L., Gibbs, D.F., Bromberg, J., Johnson, K.J., Ryan, U.S., and Ward, P.A. Endothelial cell killing by neutrophils: Synergistic interaction of oxygen products and proteases. Am. J. Pathol. 135,435-438, 1989.

32. Shalaby, M.R., Aggarwal, B.B., Rinderknecht, E., Svedersky, L.P., Finkle, B.S., and Palladino, M.A. Activation of human polymorphonuclear neutrophil functions by interferon- $\gamma$ and tumor necrosis factor. J. Immunol. 135,2069, 1985.

33. Gamble, J.R., Harlan, J.M., Klebanoff, S.J., and Vadas, M.A. Stimulation of the adherence of neutrophils to umbilical vein endothelium by human recombinant tumor necrosis factor. Proc. Natl. Acad. Sci. USA 82,8667, 1986.

34. Larrick, J.W., Graham, D., Toy, K., Lin, L.S., Senyk, G., and Fendly, B.M. Recombinant tumor necrosis factor causes activation of human granulocytes. Blood 69,640, 1987. 


\section{Ward and Varani}

35. Bevilacqua, M.P., Pober, J.S., Majeau, G.R., Fiers, W., Cotran, R.S., Gimbrone, M.A. Recombinant tumor necrosis factor induced procoagulant activity in cultured human vascular endothelial cells, characterization and comparison with the actions of interleukin-1. Proc. Natl. Acad. Sci. USA 83,4533, 1986.

36. Bevilacque, M.P., Pober, J.S., Wheeler, M.E., Cotran, R.S., and Gimbrone, M.A., Jr. Interleukin-1 acts on cultured human vascular endothelium to increase the adhesion of polymorphonuclear leukocytes, monocytes and related leukocyte cell lines. J. Clin. Invest. 76,2003, 1985.

37. Pober, J.S., Bevilacqua, M.P., Mendrick, D.L., Lapierre, L.A., Fiers, W., and Gimbrone, M.A. Two distinct monokines, interleukin-1 and tumor necrosis factor, each independently induce biosynthesis and transient expression of the same antigen on the surface of cultured human vascular endothelial cells. J. Immunol. $136,1680,1986$.

38. Varani, J., Bendelow, M.J., Sealey, D.E., Kunkel, S.L., Gannon, D.E., Ryan, U.S., and Ward, P.A. Tumor necrosis factor enhances susceptibility of vascular endothelial cells to neutrophilmediated killing. Lab. Invest. 59,292-295, 1988.

39. Friedl, H.P., Till, G.O., Ryan, U.S., and Ward, P.A. Mediatorinduced activation of xanthine oxidase in endothelial cells. FASEB J. 3,2512-2518, 1989.

40. Schuger, L., Varani, J., Marks, R.M., Kunkel, S.L., Johnson, K.J., and Ward, P.A. Cytotoxicity of tumor necrosis factor- $\alpha$ for human umbilical vein endothelial cells. Lab. Invest. 61,62-68, 1989. 